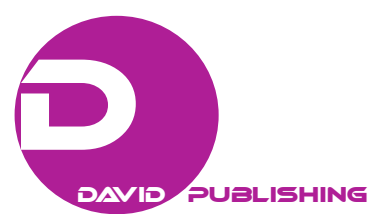

\title{
Global Financial Crisis and Islamic Financial Products
}

\author{
Gonca Atici \\ Istanbul University, Istanbul, Turkey
}

\begin{abstract}
Collapse of the United States sub-prime mortgage market in late 2006 opened a new era for the world economy. After having an average growth rate of 4.3 percent for the period of 2004-2007, world growth rate was stuck to an average of 2.2 percent between 2008-2015. While developed countries try to revitalize their economies by several unconventional monetary policies such as quantitative easing, forward guidance, and negative interest rates, emerging countries are in a rush to positively decouple from their peers in order to avoid unfavorable developments in global economic conjuncture. Still, world economy is struggling with weak investment, trade, and growth. Despite this gloomy global climate, Turkey gives a promising impression within the league of emerging economies with its expertise in crisis management. Although Turkish banking sector is the key strength of the economy, financial system should be deepened and enriched further as the economy tries to take steps to materialize the project of the Istanbul International Finance Centre. Considering the case of United Kingdom as an Islamic finance hub, it is quite clear that participating banking in Turkey could contribute more to the local conventional banking by its differentiated pool of tools. Besides, capital markets in Turkey could reach a larger audience by covering Islamic financial products in addition to the traditional range of products. A deeper and richer financial system could support the real sector by efficient allocation of resources. It can both strengthen the resilience of the economy toward potential downswings and contribute to the growth of the economy.
\end{abstract}

Keywords: financial crisis, Islamic financial products, emerging economies

\section{Introduction}

Problems that have arisen in the mortgage sector of the United States (US) as of the end of year 2006 turned into a global financial crisis by spreading from advanced countries to emerging ones. Countries that have been affected heavily from the crisis set up several bail-outs and injected abundant liquidity to the financial markets in order to stimulate their economies. Under the scope of the monetary easing policies, balance sheet of US Federal Reserve Bank reached to $\$ 4.4$ trillion as of the end of 2016 from the $\$ 1$ trillion in 2007. For the same period, balance sheet of European Central Bank increased to $\$ 3.5$ trillion from $\$ 2.1$ trillion, balance sheet of Bank of Japan reached to $\$ 4.1$ trillion from $\$ 1$ trillion and balance sheet of the People's Bank of China increased to $\$ 5$ trillion from $\$ 2.2$ trillion. In total, balance sheets of the four biggest central banks swelled from $\$ 5$ trillion in 2007 to $\$ 17.3$ trillion as of the end of 2016 which represents an increase of 246\% (Yardeni, 2017). Repercussions of these huge steps were quite positive on the side of emerging economies as capital flew into these economies for higher yields and thus they took the advantage of these resources

Gonca Atici, assoc. prof. of Finance, School of Business, Istanbul University, Istanbul, Turkey.

Correspondence concerning this article should be addressed to Gonca Atici, School of Business, Istanbul University, Avcilar 34322, Istanbul, Turkey. 
especially for their consumption expenditures and for the financing of their growth-oriented investments. Unwinding of this expansion which was signaled in May 2013, initiated a period of turbulence for emerging economies which is called "taper tantrum" (Estrada, Park, \& Ramayandi, 2015). After holding its benchmark rate near zero for seven years, US Federal Reserve Bank raised the interest rates in December 2015 as an attempt to normalization. As of the first hike, emerging market economies have kept an eye out on the US Federal Reserve Bank's monetary policies to see if the second round of hike is around the corner. As expected, second round of increase emerged at the end of 2016 and third and last rounds of increase were realized in March and June 2017, respectively. In September 2017, US Federal Reserve Bank announced the initiation of unwinding stimulus as a notice of normalization.

Advanced economies' central banks and especially US Federal Reserve Bank's actions have had a serious impact on financial markets of emerging market economies. While wave of capital supported emerging countries' lending, consumption, and growth opportunities, winds have changed as advanced economies started to normalize. Almost all emerging market economies were adversely affected in this period because they had less money to pay back their debts, finance the deficits, and spend for the expenditures. Figure 1, presents the net capital inflows to more than 40 emerging market economies. It covers all financial flows such as foreign direct investments, portfolio investments, and bank flows. The decline in net capital flows which is more than \$1 trillion from 2010 to 2015 can be linked to the increasing uncertainty, decreased prospects of growth, and lessened confidence in an environment of decreasing oil and commodity prices in emerging countries (IMF, 2016).

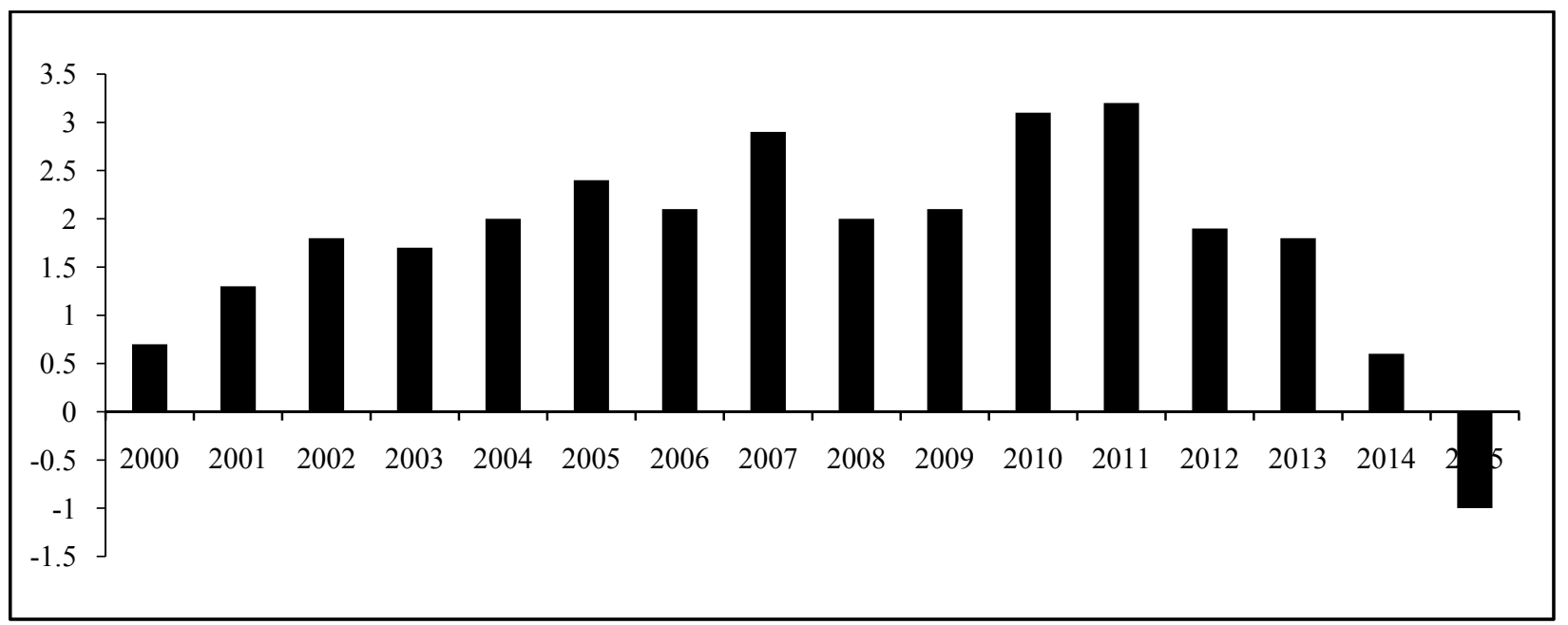

Figure 1. Net capital inflows to emerging market economies 2000-2015: Q3 (Percent of GDP).

\section{Global Financial Crisis and Emerging Economies}

Despite their resilience, emerging economies are in a struggle among themselves in a tightened environment of financial conditions, increased uncertainty, reduced global risk appetite, and other increasing risk factors. On such an occasion, the sole remedy for each of the emerging country is to provide financial stability which will enable their resistance towards crisis. Soundness of emerging economies is crucial not only for their individual stance but also for their peers, as crisis may have a boomerang effect as a result of a spillover or contagion. In order to decouple themselves from their peers and to take the advantage of 
diminishing capital flows, emerging countries seem to take steps to strengthen their economic and financial system which has a vital importance with regard to the resource allocation to the real sector.

Aftermath of the negative growth rate in an environment of global financial crisis, Turkey managed to realize an average growth rate of 5\% (TUIK) for the period of 2010-2016. In an economic atmosphere where the world economies are expected to gain momentum, Turkish economy should take further steps to accelerate its growth. In their study, Igan, Kutan, and Mirzaei (2016), discuss the channels that give way to growth (IMF, 2017). These channels are specified as funds available for investment, transmission of know-how and technology, market discipline, and better governance practices. Results of the analysis covering 28 industries in 22 emerging countries prepared for the period of 1998-2007 shed light to the effect of the first channel. Their analysis presents that industries that utilize more external finance and host more capital inflows are expected to grow disproportionately faster and smoothing of constraints benefit more to them. As Markusen and Venables (1999) suggest, integration to global financial markets goes together with a swift process of industrialization in these economies. There is a close relationship between aggregate industrial growth and capital inflows. Figure 2 presents the net portfolio investments towards Turkey for the period of 2008-2016.

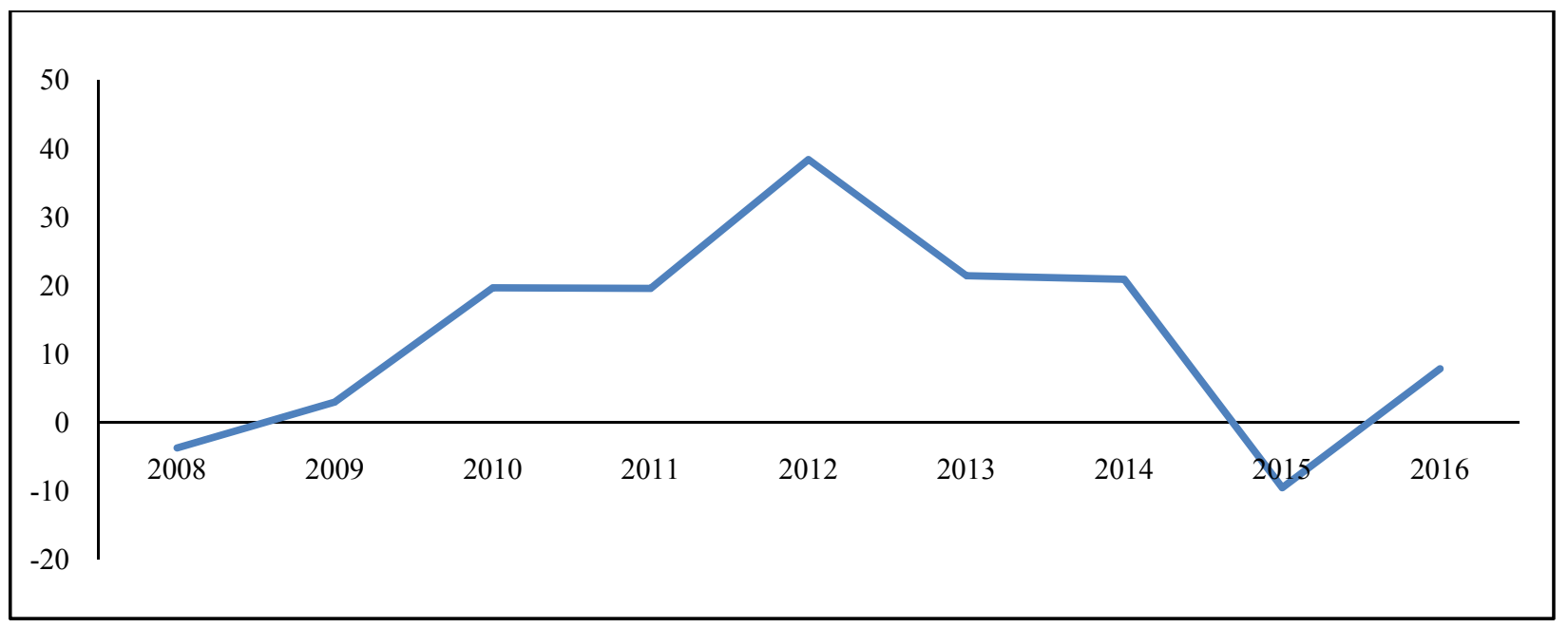

Figure 2. Net portfolio investments (USD billion). Source: CBRT.

Net portfolio investments recorded an outflow in 2015 especially due to volatile conditions in global markets. It was noteworthy to express that portfolio investments recorded a net capital outflow for the first time on annual basis since the 2008 global financial crisis. It is clear from the figure that financial system of Turkey can increase the appetite of both local and foreign investors further by providing a larger spectrum of financial products. This is also a sine qua non for the project of the Istanbul International Finance Centre.

\section{Islamic Finance and Turkish Economy}

Few empirical studies that have been conducted about Islamic finance tried to clear up the features of it. Khan (2010) investigates those features and questions to what extent Islamic banking and finance lives up to the ethical and moral practices of it and how different it is from conventional banking. Ariss (2010), analyzes Islamic and conventional banks across 13 countries for years between 2000 and 2006. She concluds that though it is less competitive, Islamic banking enables higher allocation of assets to the financing of projects by being better capitalized. Likewise, Beck, Kunt, and Merrouche (2013) compare conventional and Islamic banks by 
covering the data of 22 countries and argue that Islamic banks are better capitalized, and have high asset quality and intermediate more, especially during crises although they are less cost-effective. Besides, they emphasize that higher capitalization and better asset quality of Islamic banks led better stock performance during the global financial crisis. From a different point of view, by using Z-score as an indicator of bank stability, Bourkhis and Nabi (2013) assert that there is no significant difference in terms of the effect of the financial crisis on the soundness of Islamic banks and their commercial peers. Gheeraert (2014) in his worldwide analysis covering the period of 2000-2005 argues that Islamic banking leads to a higher banking development without crowding out the conventional banking system. In a recent study, Shaban, Duygun, Anwar, and Akbar (2014) work on the differences between conventional and Islamic banks in Indonesia. Their study reveals that Islamic banks lend more to small businesses. They argue that Islamic banks hold less capital and benefit more from lending to small businesses compared to conventional banks. They hold less capital counting on the benefits of portfolio diversification towards small business lending.

There are very little work for the case of Turkey. Ongena and Yuncu (2011) study the dataset of Turkey and try to understand the correspondence between bank type, bank orientation, and firm type. They conclude that Islamic banks mainly deal with young, multiple bank, industry-focused, and transparent firms. Cevik and Charap (2011) compare the deposit returns in Islamic banks and conventional banks in their data covering institutions in Malaysia and Turkey. The number of studies reveals the fact that there is a long way to take both in Islamic banking and finance and the researches on this field.

Although Turkish banking sector created an international success story afterwards the banking crisis of 2000-2001, this is not a sufficient condition for growth and development. Access to finance for enterprises, especially for the small and medium sized ones has become much more important in the current global conjuncture since it is clearly seen afterwards the global financial crisis that bail-outs and monetary easing policies are not enough to get countries through crisis unless the measures taken in financial sector have positive reflection in the real sector.

Turkish economy remains resilient especially with the strength of its banking sector which dominates its financial system with a share of 65.7 percent (BDDK, 2016). It attracts a considerable amount of foreign direct investment (FDI) which is almost $\$ 30$ billion over the years between 2007 and 2015. Islamic finance which is a part of the banking system was first made legal in 1985 to attract more FDI from the Gulf states. To distinguish the Islamic financial institutions from the conventional banks they were given the status of Special Finance Houses. Under the Banking Act No. 4389, Special Finance Houses were brought under the same regulations covering conventional banks. Following the amendments to the banking law, Special Finance Institutions were renamed as Participation Banks, which allowed them to integrate fully into the financial system. As presented in Table 1, participation banking in Turkey has not made up a large portion of Turkey's financial sector but it progressively gains ground as regulatory reforms have contributed more to the formalization of the sector (Aysan, Disli, \& Ozturk, 2013).

Currently, there are five participation banks operating in the Turkish banking system. The most distinguishing characteristics of participation banks are that they do not pay or charge interest on the deposits kept in banks. In contrast, they operate on profit and loss participation system in which the fund providers are allowed to receive profit at the end of a certain period (Erol, Baklac1, Aydogan, \& Tunc, 2013). As participation banks do not undertake risk of interest which is one of the most important risks that must be managed in the banking system, they are less sensitive to the financial crisis in this manner (Sayım, 2015). 
According to the regulations of Turkish banking system, participation banks also have capital buffers to protect them towards the cyclical downswings. As of the end of 2016, their CAR is $16.17 \%$ which is above the sector average of $15.57 \%$.

Table 1

Turkish Banking Sector as of the End of 2016

\begin{tabular}{llllll}
\hline Banks & $\begin{array}{l}\text { Number of } \\
\text { institutions }\end{array}$ & $\begin{array}{l}\text { Capital adequacy ratio } \\
\text { (CAR) }\end{array}$ & Asset \% & Deposits \% & Loans \% \\
\hline Participation banks & 5 & 16.17 & 4.86 & 5.59 & 4.78 \\
Deposit banks & 34 & 15.10 & 89.9 & 94.41 & 89.48 \\
Development and investment banks & 13 & 23.44 & 5.24 & 0 & 5.74 \\
Total & 52 & & 100 & 100 & 100 \\
\hline
\end{tabular}

Source: BDDK (2016; 2017), TKBB (2017).

Though Islamic finance industry structured and developed based on the demand in regions and countries such as Middle East and Malaysia, United Kingdom (UK) managed to be one of the most important financial hubs by the support of its government (CityUK, 2015). It is the first country that publicly declares its intent to adopt and develop Islamic finance to become a gateway of Islamic Finance in West (A. Malik, M. S. Malik, \& Shah, 2011). In this regard, government created a fiscal and regulatory framework intended to broaden the market for Islamic products (CityUK, 2015). Considering the Muslim population and the potential market, the UK committed to providing its citizens freedom to conduct their commercial activities (Malik et al., 2011). Currently, over 20 banks in the UK offer Islamic finance services. UK was the first Western nation to issue a sovereign Islamic bond and sukuk and the London Stock Exchange is a key global venue for the issuance of sukuk. Services in this field are offered by financial intermediaries, asset managers, and insurance, international law, accountancy and consultancy companies. As a consequence of the increasing demand for skills, UK turned to be a leading center of Islamic finance education and training with its 70 universities and business schools at undergraduate and postgraduate level (CityUK, 2015).

\section{Conclusion}

Turkish participating banking history goes back to the early 1980s and the legal infrastructure has been unified with that of conventional banking under the Banking Law No. 5411 in 2005. Although Turkish commercial banking sector is the key strength of the economy, financial system should be deepened and enriched further as the economy takes steps to realize the project of the Istanbul International Finance Centre. Considering the case of UK as an Islamic finance hub, participating banking and Islamic financial products could contribute more to the financial system by its differentiated pool of tools and methods. By this way, capital markets could reach a larger audience by covering Islamic products besides its traditional range of products. Small and medium-sized enterprises (SMEs) constitute almost $99 \%$ of the Turkish Economy. Because of this, a deeper and richer financial system could support the real sector, strengthen the resilience of the economy toward potential downswings, and contribute to the sustainable growth and development of the economy.

There is a considerable potential for Turkey to become a financial hub. First of all, as a Muslim secular country, Turkey can best understand the sensibility of the local, regional, and international investors and meet their expectations via its Islamic financial products. Transactions with Middle East and North Africa (MENA) 
region could contribute and strengthen the financial position of Turkey. By effectively employing the Islamic financial products, it can allocate the mattress saving to productive sectors and investments. It is clearly understood afterwards the global financial crisis that bail-outs and monetary easing policies are not enough to get countries through crisis unless the measures taken in the financial sector have positive repercussion in the real sector.

Global financial crisis has showed up the importance and attractiveness of Islamic finance as a component of the financial system. Islamic financial products can also be considered and supported as a cushion for the traditional system. Required skills in terms of asset management, insurance, international law, accountancy, and consultancy may lead to a transformation within the economy and to a cooperation and competition with other financial hubs. Transformation also requires the cooperation of private sector, public sector, and government. Regulatory reforms may encourage new entrants to realize technology-based transactions in this field. These efforts may contribute to the depth of the financial sector. Increasing demand for skills could also increase the involvement of universities. Universities and departments specialized on Islamic financial products may increase the dynamism within the local academia and may increase the cooperation with the international academia in this manner.

\section{References}

Ariss, T. R. (2010). Competitive conditions in Islamic and conventional banking: A global perspective. Review of Financial Economics, 19, 101-108.

Aysan, A. F., Disli, M., \& Ozturk, H. (2013). Integration of the participation banking legislations to the banking law and its influence on competition. Afro Eurasian Studies, 2, 91-110.

Bankacılık Düzenlemeve Denetleme Kurumu. (2016). Türk Bankacılık Sektörü Temel Göstergeleri 2015. Ankara, BDDK. Bankacılık Düzenlemeve Denetleme Kurumu. (2017). Türk Bankacılık Sektörü Temel Göstergeleri 2016. Ankara, BDDK.

Beck, T., Kunt, A. D., \& Merrouche, Q. (2013). Islamic vs. conventional banking: Business model, efficiency and stability. Journal of Banking \& Finance, 37, 433-447.

Bourkhis, K., \& Nabi, M. S. (2013). Islamic and conventional banks' soundness during the 2007-2008 financial crisis. Review of Financial Economics, 22, 68-77.

Cevik, S., \& Charap, J. (2011). The behavior of conventional and Islamic bank deposit returns in Malaysia and Turkey. IMF Working Paper Series, WP/11/156, 1-24.

Erol, C., Baklaci, H., Aydogan, B., \& Tunc, G. (2014). Performance comparison of Islamic (participation) banks and commercial banks in Turkish banking sector. EuroMed Journal of Business, 9, 114-128.

Estrada, G. B., Park, D., \& Ramayandi, A. (2015). Taper tantrum and emerging equity market slumps. Emerging Markets Finance and Trade, 451, 1-12.

Gheeraert, L. (2014). Does Islamic finance spur banking sector development? Journal of Economic Behavior \& Organization, 103, 4-20.

Igan, D., Kutan, A. M., \& Mirzaei, A. (2016). Real effects of capital inflows in emerging markets. IMF Working Paper, $16 / 235$.

International Monetary Fund. (2016). Too slow for too long (Chapter 2). Washington D.C. International Monetary Fund.

International Monetary Fund. (2017). World economic outlook (No: 2). Washington D.C. International Monetary Fund.

Khan, F. (2010). How "Islamic" is Islamic banking. Journal of Economic Behavior \& Organization, 76, 805-820.

Malik, A., Malik, M. S., \& Shah, H. (2011). An analysis of Islamic banking and finance in West: From lagging to leading. Asian Social Science, 7(1).

Markusen, J. R., \& Venables, A. J. (1999). Foreign direct investment as a catalyst for industrial development. European Economic Review, 43, 335-356.

Ongena, S., \& Yuncu, I. S. (2011). Which firms engage small, foreign, or state banks? And who goes Islamic? Evidence from Turkey. Journal of Banking \& Finance, 35, 3213-3224. 
Sayım, F. (2015). The participation banking as a distinctive method and its growing in the Turkish finance market-period: 2007-2013. Emerging Markets Journal, 5, 93-111.

Shaban, M., Duygun, M., Anwar, M., \& Bahrullah, A. (2014). Diversification and banks' willingness to lend to small businesses: Evidence from Islamic and conventional banks in Indonesia. Journal of Economic Behavior, 103, 39-55.

The CityUK Islamic Finance Market Advisory Group. (2015). The UK: Leading Western Centre for Islamic finance. London. Türkiye Katılım Bankaları Birliği. (2017). Türk Finans Sisteminde Katılım Bankacılı̆̆ı (Aralık 2016). İstanbul. TKBB Yardeni Research, Inc. (2017). Global economic briefing: Central bank balance sheets. USA. 